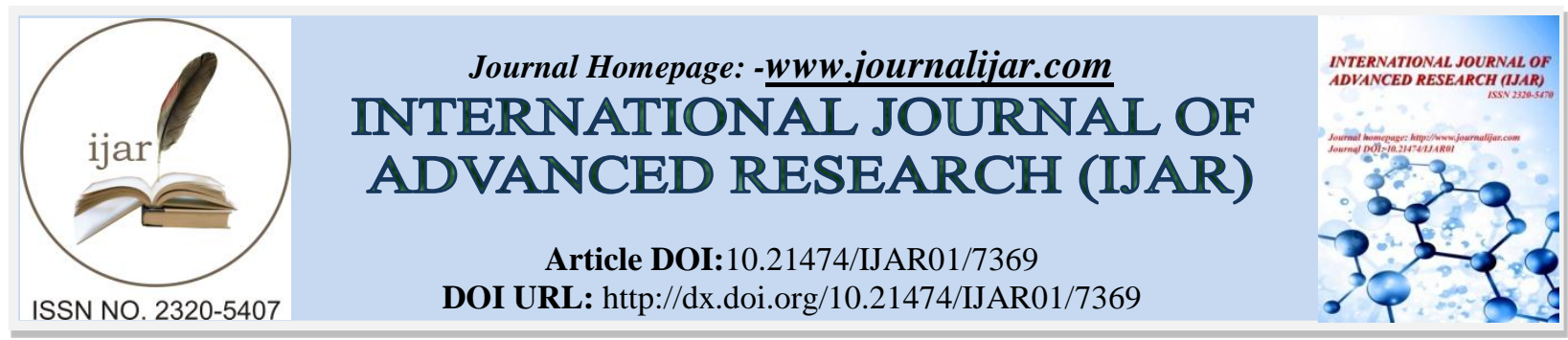

RESEARCH ARTICLE

\title{
PRELIMINARY PHARMACOGNOSTIC AND PHYSICO-CHEMICAL EVALUATION OF ROOTBARK AND STEMBARK OF GMELINA ARBOREA ROXB. HORT. BENG(San.KASMARI).
}

Dr. Sunitha. S. Nair ${ }^{1}$ and Dr. A. Shahul Hameed ${ }^{2}$.

1. PG Scholar, Dept.of Dravyagunavijnanam, Govt Ayurveda College, Thiruvananthapuram.

2. Professor, MD (Ay) Guide, Dept.of Dravyagunavijnanam, Govt Ayurveda College, Thiruvananthapuram.

\section{Manuscript Info}

Manuscript History

Received: 08 May 2018

Final Accepted: 10 June 2018

Published: July 2018

\section{Keywords:-}

Gmelina arborea Roxb. Hort. Beng., Kasmari, Pharmacognosy, Phytochemistry.

\begin{abstract}
Gmelina arborea Roxb. Hort. Beng. is a large deciduous tree belonging to the family Verbenaceae, having vast medicinal importance in Ayurveda. The plant is widely distributed throughout India. It is mentioned by the name Kasmari and is one among the ten drugs included under Dasamoola group in the Ayurvedic classics. Since the drug is being used extensively in Indian traditional medicinal systems the present work is taken up with an objective to laydown detailed pharmacognostical and preliminary phytochemical standards. The rootbark and stem bark of the plant were subjected to macroscopical and microscopical characterization, followed by preliminary physicochemical and phytochemical evaluations. The physical parameters studied included foreign matter, moisture content, volatile oil, total ash, acid insoluble ash, water soluble extractive, alcohol soluble extractive, fibre content and sugar content. The preliminary phytochemical analysis included qualitative chemical analysis, Thin Layer Chromatography, High Performance Thin Layer Chromatography and Atomic Absorption Spectroscopy. The results of the study can serve as a valuable source of pharmacognostic information adequate to set standards for its identification.
\end{abstract}

Copy Right, IJAR, 2018,. All rights reserved.

\section{Introduction:-}

Gmelina arborea Roxb. Hort. Beng (Kasmari) is one among the ten drugs included under Dasamoola group in the Ayurvedic classics. Macroscopically Kasmari is a large deciduous tree (figure 1) found throughout India( Narayana Iyer K and Kolammal M, 1978). Different parts of the plant can be used medicinally like root bark, fruit, leaf, flower, bark. It is one of the crude drugs in many of the Ayurvedic medicinal preparations like Dasamularishta, Drakshadi kwatha, Kasmaryadi panaka etc(Dr.J L N Sastry, 2014). Pharmacognostic study is the initial step to confirm the identity to assess the quality of crude drug. The adulteration of the crude drug can be detected by means of these studies. The objective of the present study is to evaluate the pharmacognostic and phytochemical parameters of the plant which will help in setting standards for identification and to ascertain the purity and quality of the plant.

Corresponding Author:- Sunitha.S.Nair.

Address:- PG Scholar, Dept.of Dravyagunavijnanam, Govt Ayurveda College, Thiruvananthapuram. 


\section{Materials And Methods:-}

Collection Of Plant Material:-

The fresh samples of rootbark and stembark of Kasmari (Gmelina arborea Roxb. Hort. Beng) were collected from the botanical garden, Poojappura, Trivandrum, Kerala. Samples were authenticated by the pharmacognosist and the voucher specimen were kept in Lab of Dept: of Dravyagunavijana, Govt Ayurveda College, Trivandrum. The collected drug was shade dried and packed in zip lock polythene bag and labeled.

\section{Macroscopic evaluation:-}

The rootbark and stembark of Kasmari (Gmelina arborea Roxb. Hort. Beng) were subjected to organoleptic evaluation. A magnifying lens was used for a better evaluation of surface characters and the observed macroscopic characters were recorded.

\section{Microscopic evaluation:-}

For microscopical studies transverse sections of rootbark and stembark were prepared and stained as per standard procedure (C.K.Kokate and A.P.Purohit, 2014).The powders of drugs were studied microscopically and the characters were observed.

\section{Materials:-}

Sharp blades, safranin stain, glass slides, cover slips, glycerin, petri dishes, brushes and digital microscope.

\section{Preliminary Physicochemical and Phytochemical evaluation:-}

The preliminary physicochemical and phytochemical analysis of the rootbark and stembark of Kasmari (Gmelina arborea Roxb. Hort. Beng) were done according to the standard procedures described in API (Ayurvedic Pharmacoepia of India, 2001), which includes: physical evaluation like evaluation of moisture content, volatile oil, total ash, acid insoluble ash, water soluble extractive, alcohol soluble extractive, fibre content and sugar content. It also includes the qualitative tests for the detection of steroids, phenols, alkaloids, flavonoids and tannins, Thin Layer Chromatography (TLC), High Performance Thin Layer Chromatography (HPTLC), and Atomic Absorption Spectroscopy (AAS).

\section{Results And Discussion:-}

\section{Macroscopic evaluation:-}

The observed macroscopical characters of rootbark, stembark and root of Kasmari (Gmelina arborea Roxb. Hort. Beng) are given in Table 1, Table 2 and Table 3.

Table 1:-Macroscopy of rootbark

\begin{tabular}{|l|l|}
\hline CHARACTERS & Rootbark \\
\hline Shape & Channeled pieces \\
\hline Size & Of varying size with 1-2 cm thickness. \\
\hline Texture & Outer membrane can be easily separated from wood in fresh root, slightly hard. \\
\hline Colour & Outer bark is dull greyish white or greyish brown; inner is lighter or cream yellow. \\
\hline Fracture & $\begin{array}{l}\text { Fresh : fibrous } \\
\text { Dry : short }\end{array}$ \\
\hline Odour & Aromatic. \\
\hline Taste & Sweetish at first, later turns slightly bitter. \\
\hline
\end{tabular}

Table 2:-Macroscopy of stembark

\begin{tabular}{|l|l|}
\hline CHARACTERS & Stembark \\
\hline Shape & Curved pieces \\
\hline Size & Length and breadth is of varying size with 1-2 cm thickness. \\
\hline Texture & Outer skin rough with longitudinal and horizontal cracks, inner is smooth \\
\hline Colour & Outer: yellowish brown, Inner: reddish brown to black. \\
\hline Fracture & Short. \\
\hline Odour & Not distinct. \\
\hline Taste & Not distinct. \\
\hline
\end{tabular}


Table 3:-Macroscopy of root

\begin{tabular}{|l|l|}
\hline CHARACTERS & Root \\
\hline Shape & Cylindrical \\
\hline Size & Of varying size \\
\hline Texture & fairly smooth, though uneven and sparsely lenticellate \\
\hline Colour & Greyish white to greyish brown \\
\hline Fracture & Short \\
\hline Odour & Aromatic \\
\hline Taste & Sweetish at first, later turns slightly bitter. \\
\hline
\end{tabular}

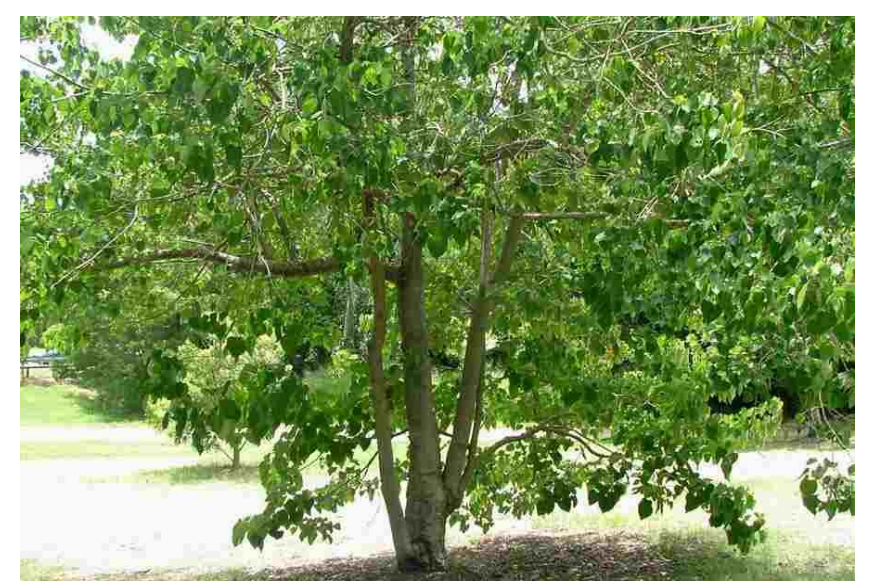

Figure 1:-whole plant of Gmelina arborea Roxb. Hort. Beng

Microscopic evaluation:-

The histological evaluation of root bark of KASMARI (Gmelina arborea Roxb. Hort. Beng) (figure 2):-

Cork tissue consists of 25 to 40 slightly wavy rows of thin walled rectangular cells. Cortex consists of 20-40 rows of thin walled compactly arranged cells. Oblong or spherical groups of cubical or rectangular or polygonal stone cells with thick pitted walls. Terminal portions of the medullary rays are extending to the periphery of the cortex. Bast forms the widest part and has several rows of parenchymatous cells, which contains aggregates of minute starch grains each group composed of 2- 5 particles. Medullary rays are broad and 3- 5 or more seriate. Cambium together with newly formed cells appears as a strip of annular tissue.

The histological evaluation of stem bark of KASMARI (Gmelina arborea Roxb. Hort. Beng) (figure 3) :Transverse section of stembark shows a wide zone of cork consisting of rectangular, thick walled lignified cells. Cork cambium 1 or 2 layers, filled with reddish brown contents. Secondary cortex consists of 2 or 3 layers, tangentially elongated, elliptical parenchymatous cells. Secondary phloem composed of sieve elements, parenchyma and phloem rays. Stone cells oval to elliptical lignified pitted with wide lumen. Lysigenous cavities present throughout the phloem.

\section{The histological evaluation of root of KASMARI (Gmelina arborea Roxb. Hort. Beng) (figure 4):-}

Transverse section of root shows 6-8 layers of cork cells, secondary cortex, including primary and secondary phloem about two third consisting of wood. Cork brownish, cells arranged in tangential direction and broken at places towards upper layers. Cortex characterized by the presence of thin-walled parenchymatous cells with starch grains. Resin ducts present in abundance throughout cortex, scattered stone cells fibre like or elongated common. Cells of cortex also contain rosette crystals of calcium oxalate and oil globules medullary rays generally 1-2 celled thick with abundant starch grains cells oblong to rectangular. Wood consists of simple pitted wood parenchyma and medullary rays, lumen of vessels are somewhat large. 


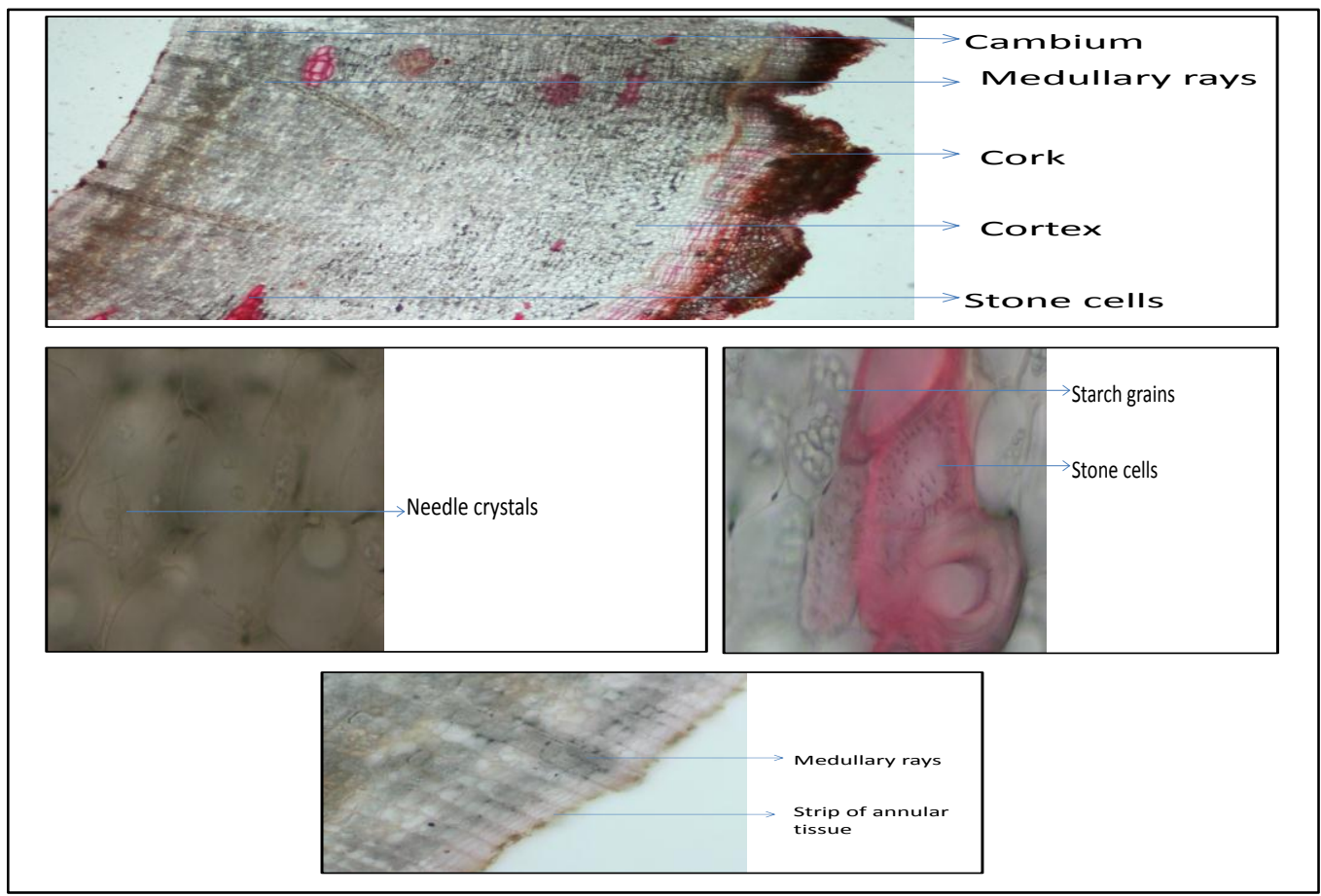

Figure 2:-transverse section of rootbark of Kasmari



Figure 3:-transverse section of stembark of kasmari

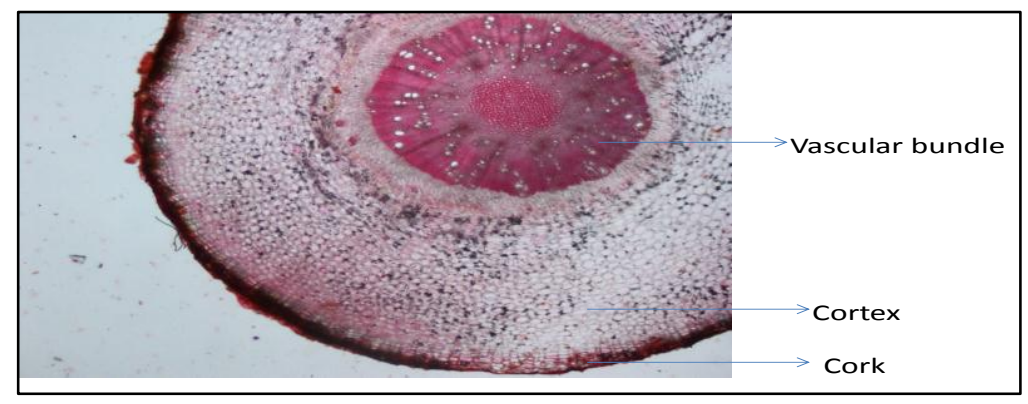

Figure 4:-transverse section of root of Kasmari 
The powder microscopy of root bark of KASMARI (Gmelina arborea Roxb. Hort. Beng) (figure 5):-

Fragments showed presence of mucilage and group of stone cells. Bordered pitted xylem vessels, vessel with fibres and xylem parenchyma were present. Presence of calcium oxalate crystals and cork cells found. Starch grains, medullary rays and fibres were also found.

The powder microscopy of stem bark of KASMARI (Gmelina arborea Roxb. Hort. Beng) (figure 6):-

Reddish brown and shows fragments of cork cells. Thick walled elliptical lignified, pitted stone cells are present. Also pitted vessels and crystals were found.

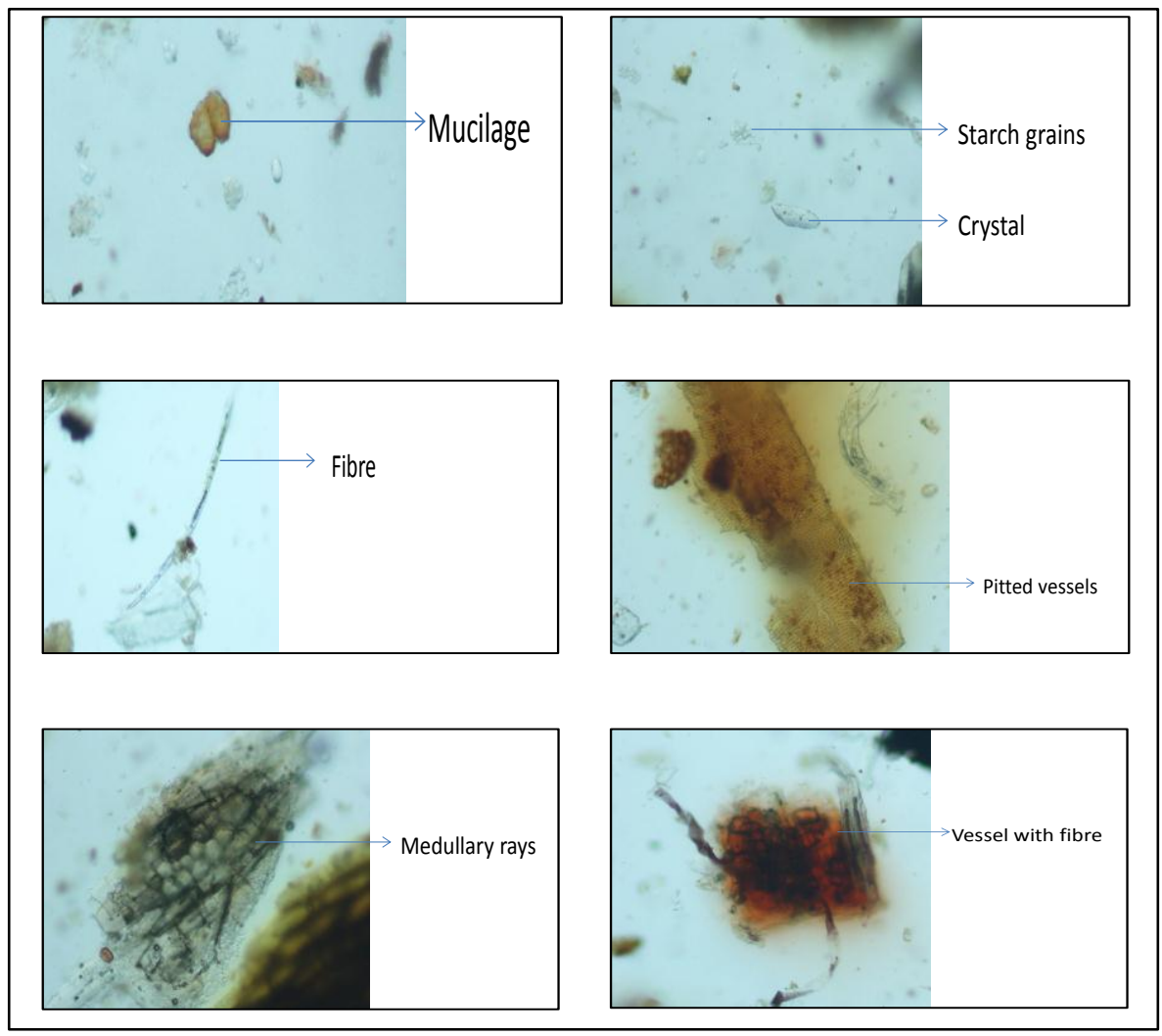

Figure 5:-Powder microscopy of rootbark of Kasmari

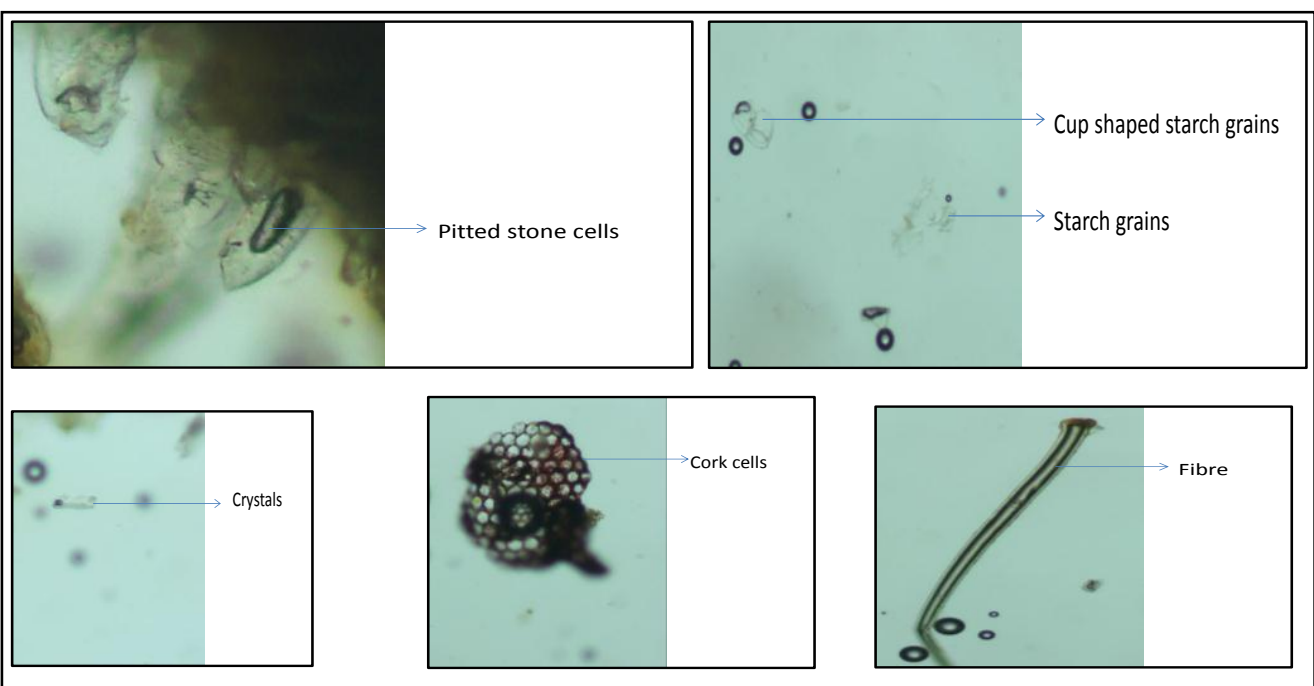

Figure 6:-Powder Microscopy Of Stembark Of Kasmari 


\section{Results of physico-chemical evaluation:-}

Preliminary physical and physico-chemical analysis were done and the results are summarized in Table No: 3 . The ash values of a drug give an idea of the inorganic composition and other impurities present along with the drug and the value was more in stembark $(4.15 \%)$ than rootbark $(2.06 \%)$. Estimation of extractive values determines the amount of the active constituents in a plant material when extracted with a particular solvent. The high water solubility of the contents than alcohol solubility of both stembark and rootbark suggests aqueous extract for future studies.

Table 3:-Preliminary physicochemical analysis

\begin{tabular}{|l|l|l|l|}
\hline Sl no & Name of experiment & rootbark & stembark \\
\hline 1 & Foreign matter & Nil & Nil \\
\hline 2 & Moisture content & Traces & 3.9 \\
\hline 3 & Volatile oil(\%) & Traces & Traces \\
\hline 4 & Total ash (\%) & 2.066 & 4.15 \\
\hline 5 & Acid insoluble ash (\%) & 0.076 & 0.509 \\
\hline 6 & ater soluble extractive (\%) & 23.81 & 33.26 \\
\hline 7 & Alcohol soluble extractive (\%) & 8.914 & 7.82 \\
\hline 8 & Fibre content (\%) & 47.32 & 42.52 \\
\hline 9 & Sugar content & 2.3 & 2.5 \\
\cline { 2 - 4 } & & Reducing sugar $(\%)$ & 4.1 \\
\hline
\end{tabular}

\section{Results of preliminary phytochemical analysis:-}

The ethanolic extractive obtained was subjected to qualitative analysis for identification of various plant constituents like steroids, phenols, alkaloids, flavonoids, tannins and results were summarized in Table No:4. The presence of different plant constituents determines the pharmacological action and therapeutic potential of that plant. The preliminary phytochemical screening of stembark showed the presence of different phytoconstituent groups such as steroid, flavonoid, saponin, alkaloid and tannin. The rootbark showed the presence of steroid, phenol, saponin, alkaloid and tannin.

Table 4:-The results of Qualitative chemical analysis of alcoholic extract

\begin{tabular}{|l|l|l|l|}
\hline Sl no & Chemical constituent & Root bark & stembark \\
\hline 1 & Steroid & ++ & ++ \\
\hline 2 & Flavonoid & - & + \\
\hline 3 & Phenol & + & - \\
\hline 4 & Alkaloid & + & ++ \\
\hline 5 & Tannin & + & + \\
\hline 6 & Saponin & + & + \\
\hline
\end{tabular}

Results of TLC and HPTLC:-

The spots obtained in TLC gives a rough idea about the study plant constituents. The best separation was achieved using Chloroform: Ethyl acetate: Benzene- 6:2:3. for both rootbark and stembark. The plates were first viewed through UV-fluorescence viewing cabinet $(365 \mathrm{~nm})$ and the Rf values of the spots were noted (Table No: 5). HPTLC was done and the HPTLC profile was shown in figure 7 and its 3D scan profile was shown in figure 8.

Table 5:-Rf values of spots obtained in Chromatography

\begin{tabular}{|l|l|l|l|}
\hline Solvent system with ratio & Sample & No of spots & Rf value \\
\hline Chloroform: Ethyl acetate: Benzene- & Rootbark & 6 & 0.65 \\
6:2:3. & & & 0.17 \\
& & & 0.25 \\
& & & 0.32 \\
& & 0.26 \\
& & 4 & 0.18 \\
\cline { 2 - 4 } & Stembark & 0.60 \\
\hline
\end{tabular}




\begin{tabular}{|l|l|l|l|}
\hline & & 0.34 & 0.17 \\
& & & 0.25 \\
\hline
\end{tabular}

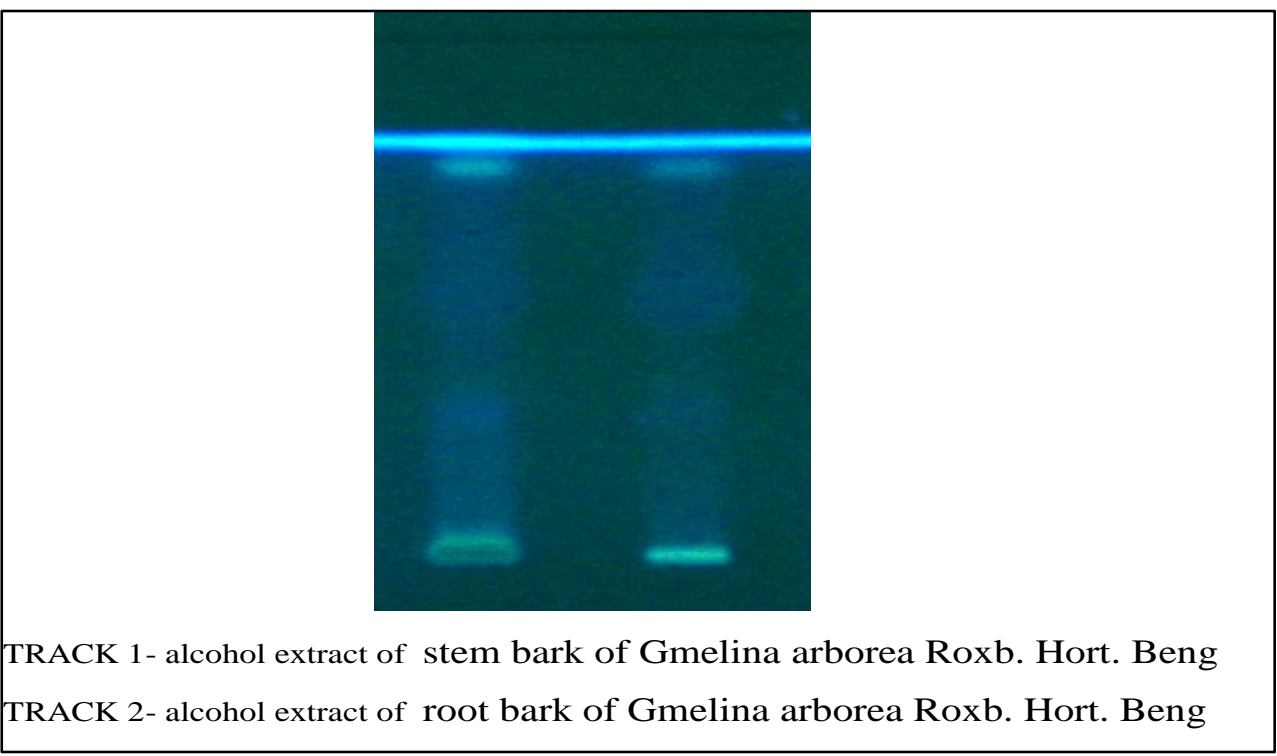

Figure 7:-HPTLC of Kasmari stembark and rootbark with solvent system Chloroform: Ethyl acetate : Benzene$6: 2: 3$.

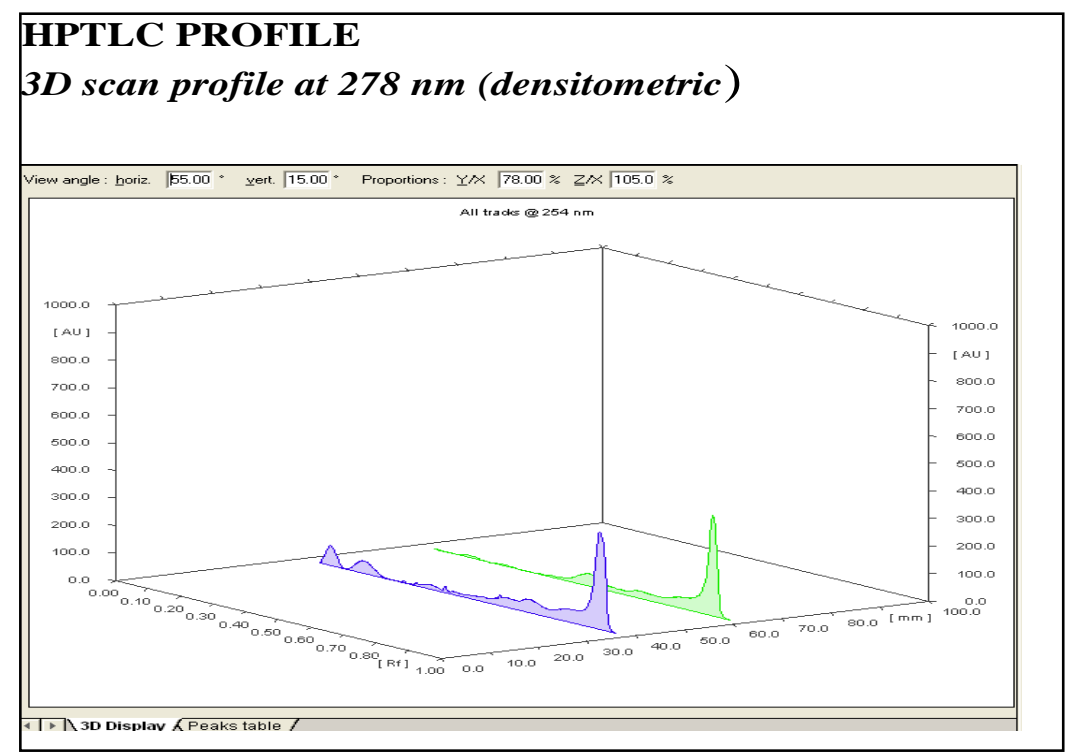

Figure 8:-3D scan profile with solvent system Chloroform: Ethyl acetate: Benzene- 6:2:3.

\section{Results of Atomic Absorption Spectroscopy:-}

Atomic absorption spectroscopy is used in the determination of heavy metal elements and some non-metal elements in atomic state and the results were shown in Table No: 6. Four heavy metals- copper, cadmium, iron and lead contents were found within permissible limits. Hence the drug is not contaminated by heavy metals and can be used safely for internal administration. 
Table 6:-Atomic absorption spectroscopy

\begin{tabular}{|c|c|c|c|c|}
\hline \multirow[t]{2}{*}{ Samples } & \multicolumn{4}{|c|}{ Heavy metal concentration (in ppm) } \\
\hline & $\mathrm{Cu}$ & Cd & $\mathbf{F e}$ & $\mathbf{P b}$ \\
\hline Rootbark & 0.1100 & 0.0446 & 4.1553 & 0.1278 \\
\hline Stembark & 0.1167 & 0.0462 & 4.7820 & 0.1293 \\
\hline
\end{tabular}

\section{Conclusion:-}

Macroscopy and microscopy along with the preliminary phytochemical evaluation of stembark and rootbark confirm the quality and purity of plant and its identification. On physico chemical analysis the stembark was found with relatively high total ash value $(4.15 \%)$. The preliminary phytochemical screening of stembark showed the presence of different phytoconstituent groups such as steroid, flavonoid, saponin, alkaloid and tannin. The rootbark showed the presence of steroid, phenol, saponin, alkaloid and tannin. AAS evidenced that the drug is not contaminated by heavy metals and can be used safely for internal administration. Here the observations and results obtained useful for further pharmacological and therapeutical evaluation.

\section{Acknowledgement:-}

The authors are thankful to Department of Dravyagunavijnanam and Drug Standardisation Unit, Government Ayurveda College, Thiruvananthapuram for all the recordings made thereof.

\section{References:-}

1. Narayana Iyer K, Kolammal M. Pharmacognosy of Ayurvedic Drugs, Kerala Number2, 1 ed. Thiruvananthapuram: Pharmacognosy Unit, Ayurveda College; 1978. p. 47-54

2. Dr.J L N Sastry, Illustrated Dravyagunavijanana. VOL 2.Reprint ed. Varanasi: Chaukhambha Orientalia; 2014. P.426.

3. C.K.Kokate,A.P.Purohit, S.B. Gokhale. Pharmacognosy. 50th. Pune; Nirali prakashan; 2014.1-15.

4. Anonymous. The Ayurvedic Pharmacopoeia of India. Part-1, Vol. 3,Govt. of India. Ministry of health and Family welfare, Dept. of ISM\&H(AYUSH), New Delhi, 2001, 227-40. 